\title{
MEDIA PEMBELAJARAN INTERAKTIF UNTUK MENINGKATKAN MINAT SISWA BELAJAR MATEMATIKA DI SMP 1 BUKIT SUNDI
}

\author{
Suci Wulandari \\ Universitas Mahaputra Muhammad Yamin \\ Email: suciwulandari04@yahoo.com
}

(Naskah masuk: 21 Juni 2020, diterima untuk diterbitkan: 27 Juni 2020)

\begin{abstract}
Abstrak
Kurangnya minat siswa dalam mempelajari matematika disebabkan karena beberapa siswa menggangap bahwa pelajaran matematika merupakan sebuah mata pelajaran yang sulit di karenkan banyaknya rumus-rumus, serta matematika merupakan mata pelajaran yang membosankan begitulah fikir para siswa dan metode pembelajaran yang diterapkan para guru masih konvensional sehingga menyebabkan siswa tidak tertarik untuk mempelajari matematika. Maka dari itu penulis membuat media pembelajaran interaktif yang nantinya Penelitian ini bertujuan untuk mengetahui bagaimana media pembelajaran berbasis multimedia interaktif dapat mempengaruhi minat belajar siswa. apabila dari siklus perkembangan minat belajar siswa di dapatkan angka yang signifikan dari penggunaan media pembelajaran interaktif siswa cenderung semangat dan menyukai pelajaran matematika maka Dari hasil penelitian ini dapat disimpulkan bahwa media pembelajaran berbasis multimedia interaktif memberikan pengaruh positif terhadap pembentukan minat belajar siswa khususnya pada mata pelajaran matematika.
\end{abstract}

Kata kunci: pelajaran matematika, media pembelajaran, multimedia interaktif

\section{INTERACTIVE LEARNING MEDIA TO INCREASE STUDENTS' INTEREST IN LEARNING MATHEMATICS AT SMP 1 BUKIT SUNDI}

\begin{abstract}
The lack of student interest in learning mathematics is due to some students assuming that mathematics is a difficult subject because of the large number of formulas and mathematics is a boring subject that's how students think and the learning methods applied by teachers are still conventional so that students do not interested in studying mathematics. Therefore the writer makes interactive learning media which later this study aims to find out how interactive multimedia-based learning media can affect student learning interest. if from the development cycle of student interest in learning get a significant number of the use of interactive learning media students tend to be passionate and like math lessons. From the results of this study it can be concluded that interactive multimedia-based learning media has a positive influence on the formation of student learning interest, especially in mathematics subjects .
\end{abstract}

Keywords: mathematics lessons, instructional media, interactive multimedia

\section{PENDAHULUAN}

Pelajaran MATEMATIKA merupakan salah satu pelajaran utama yang diajarkan tidak hanya di sekolah dasar tapi di setiap jenjang pendidikan yang bertujuan untuk mengembangkan kemampuan berpikir siswa. Matematika juga melatih kemampuan konsestrasi para siswa dimana seperti yang kita ketahui matematika tidak hanya memperkenalkan konsep, keterampilan dan strategi berpikir namun juga rumus-rumus yang melatih siswa memecahkan soal-soal yang diberikan. Belajar matematika merangsang rasa ingin tahu, mendorong kreativitas dan melengkapi siswa dengan keterampilan yang dibutuhkan dalam kehidupan di luar sekolah.

Herman Hudojo (2005: 135) menyatakan bahwa pembelajaran matematika berarti pembelajaran tentang konsep-konsep atau struktur-struktur yang terdapat dalam bahasan yang dipelajari serta mencari hubungan-hubungan antara konsep-konsep atau 
struktur-struktur tersebut.Sesuai dengan pengertian di atas, pembelajaran matematika seharusnya dilaksanakan secara terpadu dengan mengoptimalkan peran siswa sebagai pembelajar. Siswa tidak hanya mendapatkan pemahaman konsep tetapi siswa juga diharapkan memiliki keterampilan dan kreativitas dalam belajar matematika sehingga mampu menerapkannya dalam menyelesaikan masalah sehari-hari.

Namun pada kenyataannya pelajaran matematika merupakan salah satu pelajaran yang ditakuti oleh sebagian siswa karena matematika tidak jarang di anggap sulit oleh siswa karena banyaknya rumusrumus yang digunakan karena matematika merupakan mata pelajaran yang mengutamakan sarana berpikir untuk mengkaji sesuatu secara logis dan juga sistematis.

Beberapa factor yang menyebabkan siswa malas untuk belajar matematika juga dikarenakan situai belajar yang kurang mendukung dan factor lainnya adalah karena sarana berpikir dalam pembelajaran matematika haruslah berstruktur, artinya jika siswa tidak menguasai materi-materi dasar matematika dengan kuat maka siswa akan merasa sulit untuk mengikuti materi-materi matematika selanjutnya. Sehingga ketika siswa sudah merasa sulit untuk mencerna materi, siswa akan merasa bosan dan ketika siswa masuk dalam situasi tes siswa akan merasa kesulitan untuk mengerjakan soal matematika dikarenakan siswa tidak mempunyai dasar yang kuat dalam mata pelajaran matematika hal ini mengakibatkan mata pelajaran matematika dicap sebagai mata pelajaran yang sulit.

Masalah yang terjadi ini tidak terlepas dari peranan seorang guru. Dalam hal ini Guru sebagai fasilitator dalam kegiatan pembelajaran memegang peranan penting dalam peningkatan kualitas siswa dan prestasi belajar siswa terutama dalam belajar matematika. Guru harus benar memperhatikan sekaligus merencanakan proses pembelajaran yang menarik bagi siswa, agar siswa semangat dalam belajar dan mau terlibat dalam proses pembelajaran, sehingga pembelajaran tersebut menjadi efektif.

\section{LANDASAN TEORI}

Untuk mengatasi permasalahan di atas maka di buatlah media pembelajaran interaktif yang nantinya dapat meningkatkan semangat belajar siswa serta mengurangi rasa bosan untuk mempelajari matematika bagi siswa tekhususnya siswa pada smp 1 Bukit Sundi.

\subsection{Pelajaran Matematika}

matematika adalah pola berfikir, pola mengorganisasikan, pembuktian yang logis. Matematika adalah bahasa yang menggunakan istilah yang didefinisikan dengan cermat, jelas, akurat, representasinya dengan symbol dan padat, lebih berupa bahasa simbol mengenai ide-ide.

Perkembangan teknologi dalam dunia pendidikan tidak terlepas dari ilmu matematika, hanya saja itu semua bertolak belakang dengan peran penting matematika, faktanya masih banyak peserta didik yang menganggap matematika pelajaran yang sulit (Putra, 2015, 2017).

Permendiknas No. 22 Tahun 2006 tentang Standar Isi menyatakan bahwa salah satu tujuan pembelajaran matematika pada semua jenjang pendidikan dasar dan menengah adalah agar peserta didik memecahkan masalah yang meliputi kemampuan memahami masalah, merancang model matematika, menyelesaikan model dan menafsirkan solusi yang diperoleh. Dari tujuan pembelajaran tersebut nampak bahwa tujuan pembelajaran matematika di Indonesia menekankan pada pemecahan masalah (Muhammad istiqlal, 2017).

Matematika berfungsi mengembangkan kemampuan menghitung mengukur, menurunkan dan menggunakan rumus matematika yang diperlukan dalam kehidupan sehari-hari melalui materi aljabar, geometri, logika matematika, peluang dan statistika. Matematika juga berfungsi mengembangkan kemampuan mengkomunikasikan gagasan melalui model matematika yang dapat berupa kalimat dan persamaan matematika, diagram, grafik atau table.

\subsection{Media Pembelajaran}

Media pembelajaran secara umum adalah alat bantu proses belajar mengajar. Segala sesuatu yang dapat dipergunakan untuk merangsang pikiran, perasaan, perhatian dan kemampuan atau ketrampilan pebelajar sehingga dapat mendorong terjadinya proses belajar. Batasan ini cukup luas dan mendalam mencakup pengertian sumber, lingkungan, manusia dan metode yang dimanfaatkan untuk tujuan pembelajaran / pelatihan.

Media secara harfiah dipat dimaknai sebagai tengah, pengantar atau perantara. yang mengantarai kedua sisi tersebut. Karena posisinya berada di tegah ia bisa juga disebut sebagai pengantar atau penghubung, yakni yang mengantarkan atau menghubungkan atau menyalurkan sesuatu hal dari satu sisi ke sisi lainnya (Muhammad istiqlal,2017) dalam (Munadhi, 2008).

media pembelajaran mencakup sarana fisik untuk menyampaikan isi/materi pembelajaran seperti : buku, film, video dan sebagainya. Kemudian menurut National Education Associaton(1969) mengungkapkan bahwa media pembelajaran adalah sarana komunikasi dalam bentuk cetak maupun pandang-dengar, termasuk teknologi perangkat keras.

\subsection{Media Interaktif}

Multimedia interaktif adalah suatu multimedia yang dilengkapi dengan alat pengontrol yang dapat dioperasikan oleh pengguna, sehingga pengguna dapat Pengimplemantasian Media Pembelajaran Berbasis Multimedia Interaktif pada Mata Pelajaran Matematika. Contoh multimedia interaktif adalah pembelajaran interaktif, aplikasi game, dll. Media 
pembelajaran interaktif berbasis multimedia digunakan untuk menyalurkan pesan (pengetahuan, keterampilan dan sikap) serta dapat merangsang pilihan, perasaan, perhatian dan kemauan siswa sehingga secara sengaja proses belajar terjadi, bertujuan dan terkendali.

Karakteristik media pembelajaran interaktif multimedia adalah sebagai berikut: 1.Memiliki lebih dari satu media yang konvergen, misalnya menggabungkan unsur audio dan visual. 2.Bersifat interaktif, dalam pengertian memiliki kemampuan untuk mengakomodasi respon pengguna. 3.Bersifat mandiri, dalam pengertian memberi kemudahan dan kelengkapan isi sedemikian rupa sehingga pengguna bisa menggunakan tanpa bimbingan orang lain. Berdasarkan karakteristik tersebut maka sebuah media pembelajaran multimedia interaktif yang baik memiliki tampilan yang menarik karena dikemas dalam berbagai media, mudah digunakan serta bermanfaat bagi pembelajaran.

\subsection{Macromedia Flash}

Macromedia Flash merupakan aplikasi yang digunakan untuk melakukan desain dan membangun perangkat presentasi, publikasi, atau aplikasi lainnya yang membutuhkan ketersediaan sarana interaksi dengan penggunanya. Proyek yang dibangun dengan Flash bisa terdiri atas teks, gambar, animasi sederhana, video, atau efek-efek khusus lainnya.

Aplikasi Macromedia Flash mampu menciptakan animasi dan simulasi pembelajaran. Selain itu ditinjau dari hasil pembelajarannya bahwa respon siswa lebih tertarik pembelajaran meggunakan media pembelajaran berbasis Macromedia Flash (Masykur, Nofrizal, \& Syazali, 2017).

\section{METODOLOGI PENELITIAN}

Metode penelitian yang dilakukan dalam penelitian ini adalah metode pengumpulan data, yaitu metode observasi, wawancara dan studi pustaka. Karena penelitian ini bertujuan menggambarkan atau menguraikan permasalahan yang ada sekarang berdasarkan data-data yang diperoleh dan dikumpulkan pada saat melakukan penelitian.

\subsection{Lokasi dan Waktu Penelitian}

Penelitian dilakukan pada SMPN 1 BUKIT SUNDI yang beralamat di Jl.Muara Panas Panyalai, Koto Baru Bukit Sundi Kecamatan kubung Kabupaten Solok,Penelitian berlangsung selama 3 (tiga) bulan.

\subsection{Metode Pengumpulan Data}

Metode pengumpulan data tentang jenis dan sumber data serta teknik pengumpulan data yang digunakan selama penelitian adalah :

\section{Wawancara:}

Metode ini dilakukan dengan cara pengambilan dan pengumpulan data siswa dan sisiwi berdasarkan hasil wawancara dari guru yang mengajar di mata pelajaran matematika kemudian melalukan wawancara langsung kepada sebagian siswa dan sisiwi mengenai tanggapan mereka terhadap pelajaran matematika.

2. Studi perpustakaan :

referensi yang digunakan bersumber dari jurnal-jurnal yang didapat pada internet sesuai dengan judul yang diangkat. Pada metode ini penulis melakukan pengumpulan informasi mengenai semangat belajar siswa dan sisiwi terkhususa pada mata pelajaran matematika dengan mempelajari buku-buku dan referensi yang berhubungan dengan konsep matematika dan peran penting mempelajari matematika pada setiap bidang pendidikan. koperasi simpan pinjam. Metode studi pustaka ini digunakan sebagai referensi dalam penyusunan dan pencarian informasi yang akurat tentang konsep matematika.

3. Analisis :

Proses pembelajaran sebelumnya dilakukan secara manual menggunakan bahan ajar yang mana dengan cara tersebut siswa dan siswi merasa kesulitan memahami konsep serta menguasai rumus-rumus pada matematika sehinnga dibutuhkan sebuah media pembelajaran interaktif yang membuat susasana belajar yang lebih menarik serta meningkatkan minat siswa untuk mempelajari matematika.

4. Perancangan:

Untuk merancang media pembelajaran berbasis multimedia interaktif menggunakan macromedia flash.

5. Pemograman

Untuk membangun media pembelajaran berbasis multimedia interaktif menggunakan macromedia flash.

6. Uji coba

Kegiatan uji coba yang dilakukan untuk melihat hasil perancangan merancang media pembelajaran berbasis multimedia interaktif menggunakan macromedia flash yang telah dibuat.

\section{HASIL DAN PEMBAHASAN}

Media pembelajaran berbasis multimedia interaktif ini terdiri dari 3 komponen utama yaitu tujuan pembelaran materi dan evaluasi. Ketiga komponen ini dapati digunakan guru sebagai alat bantu dalam proses pembelajaran dan bisa juga digunakan siswa untuk mempermudah dalam belajar mandiri dan memahami materi terutama mata pelajaran matematika. Pada setiap tampilan komponen, siswa sebagai pengguna dapat melakukan interaksi dengan system pada aplikasi media pembelajaran yang dilengkapi dengan tampilan yang menarik dan bahasa yang sederhana dalam bentuk gambar dan audio.

Ini akan memudahkan siswa dalam memproses informasi dan memdapatkan suasana yang 
menyenangkan dalam dari bermain games. Kondisi tersebut akan menggerakkan motivasi instrinsik dan memunculkan minat belajar siswa terhadap objek pada media. Siswa sebagai pengguna memiliki control penuh untuk memilih materi yang akan diperlajari, memilih waktu untuk mengerjakan tes dan menentukan target skor dalam bermain game. Dengan demikian kemandirian siswa dalam belajar dan kebebasan untuk menentukan cara penggunaan media bagi guru maupun siswa dapat terfasilitasi.

\subsection{Tampilan Menu Utama}

Pada tampilan awal akan muncul menu utama dimana terdapat 3 komponen yaitu tujuan pembelajaran, materi dan evaluasi apabila siswa dan siswi belum mengetahui bagaimana silabus dan tujuan pembelajaran maka siswa dan siswi tersebut dapat membuka tujuan pembelajaran dan begitu seterusnya apabila siswa merasa ingin menguji seberapa kemampuan mereka dalam mempelajari materi yang diberikan guru pada media tersebut maka siswa dapat melakukan evalusi dengan menjawab beberapa pertanyaan yang berkaitan dengan materi yang sudah diberikan dengan begitu siswa dapat melihat sejauh mana materi tersebut sudah mereka kuasai.

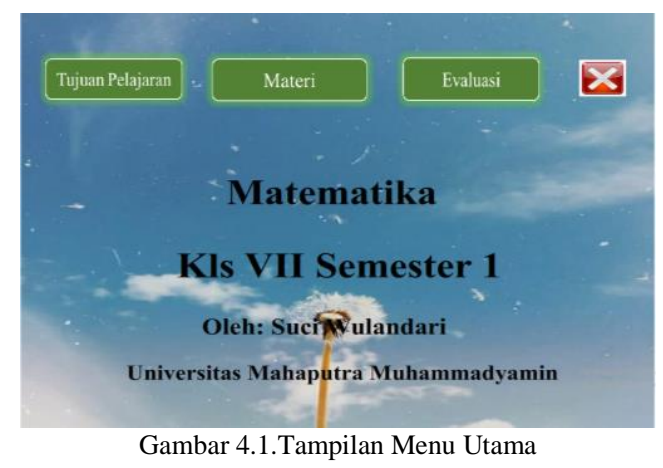

\subsection{Menu Materi}

Pada menu materi siswa dapat menemukan materi yang akan di pelajari pada setiap pertemuannya misalnya untuk pertemuan pertama mengenai bilangan bulat begitu pun seterusnya untuk setiap pertemuan dari materi yang diberikan. Pada materi pertama tersebut guru telah memberikan konsep yang jelas contohnya materi pertama membahas tentang bilangan bulat seperti perkalian, pengurangan, pembagian dan penambahan. guru yang mengajar di mata pelajaran matematika tersebut akan memberikan materi yang detail mengenai deskripsi masing-masing bilangan bulat agar para siswa dapat menguasai dengan baik konsep bilangan bulat seperti menjelaskan sifat-sifat serta memberikan beberapa contoh pada masingmasing penjelaan. Dengan kemasan seperti ini maka konsep bilangan bulat pada matematika dapat dipelajari oleh siswa dengan mudah dan mereka pun menjadi lebih tertarik karena adanya beberapa contoh yang diberikann sehingga dapat membentuk minat belajar siswa
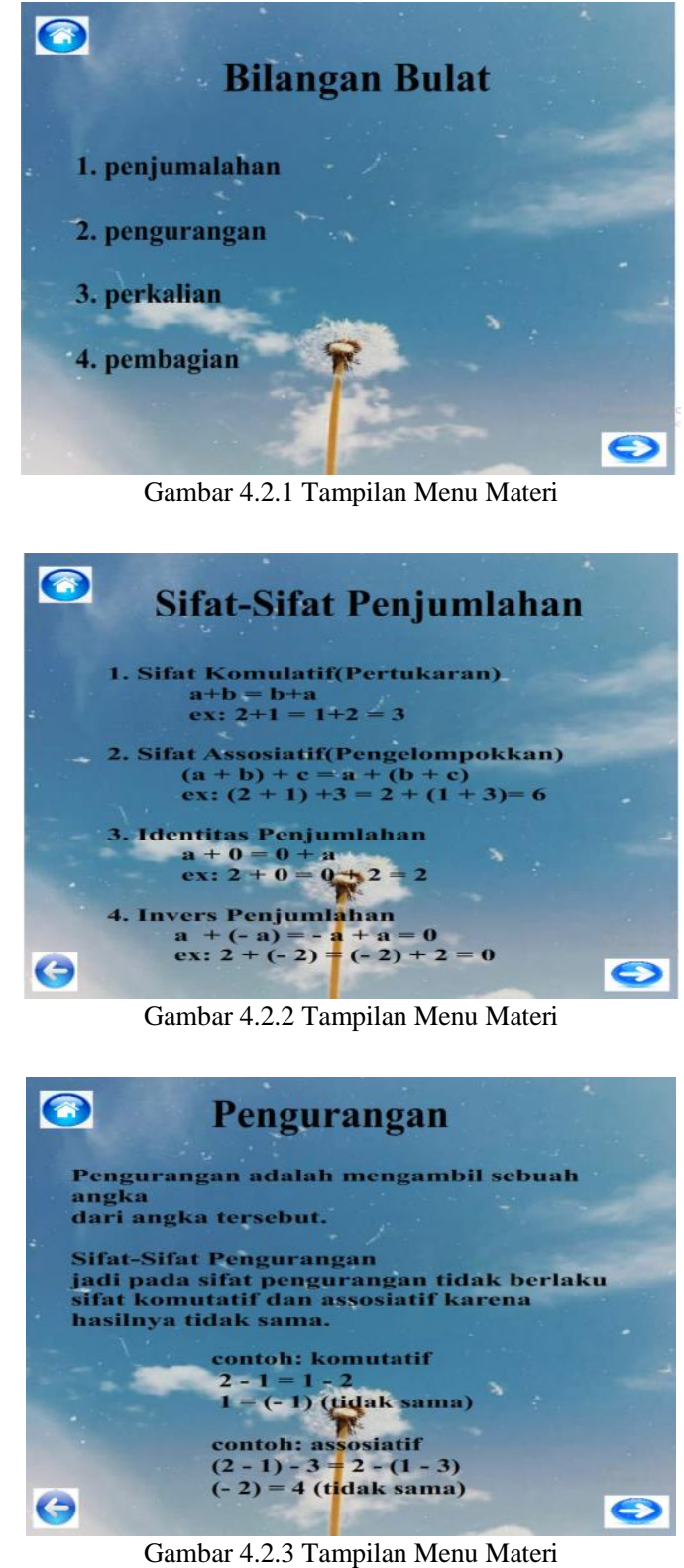

\subsection{Tampilan Menu Evaluasi}

Menu evaluasi terdapat soal-soal yang dapat dikerjakan siswa untuk mengukur kemampuannya sendiri setelah mempelajari materi-materi yang diberikan guru dengan adanya evaluasi siswa tersebut dapat mengukur sejauh mana kemampuan mereka menguasai materi yang telah diberikan. Soal latihan yang ada pada media interaktif dibuat dengan merujuk pada indikator pencapaian yang terdapat dalam SKKD. Soal yang dikerjakan berjumlah 5 buah yang sesuai dengan masing-masing materi. Soal yang tampil pada media pembelajaran interaktif yang dibuka siswa satu dengan siswa yang lain pada waktu yang sama akan berbeda.

Hal ini bertujuan untuk memperkecil kemungkinan siswa untuk bekerjasama dengan siswa yang lain, sehingga kemampuan siswa dalam memahami. Dengan adanya konsep belajar seperti ini maka siswa di harapkan tidak bosan dengan cara 
belajar menggunakan media interaktif di banding belajar secara konvensional yang monoton sehingga semangat dan kemampuan belajar siswa khususnya pada mata pelajaran matematika bisa di tingkatkan. Pada menu evaluasi apabila siswa masih kesulitan menjawab sola dan beberapa pertanyaan tidak berhasil di jawab dengan benar maka siswa tersebut dapat mengulang kembali menjawab soal-soal tersebut sampai skor nilai mereka mencapai 100.
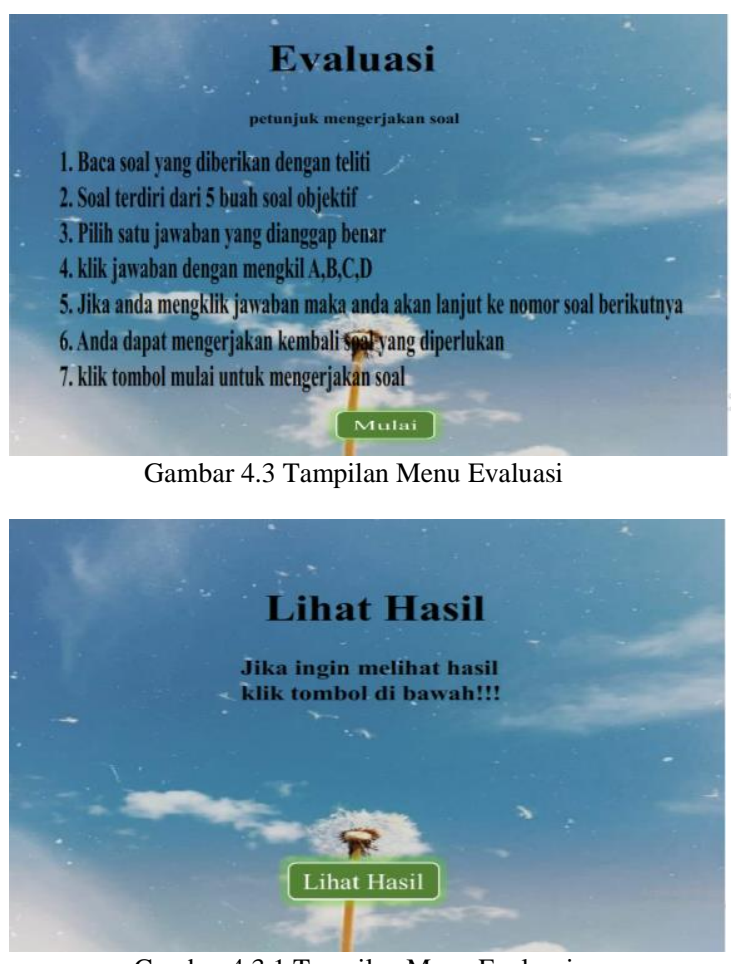

Gambar 4.3.1 Tampilan Menu Evaluasi

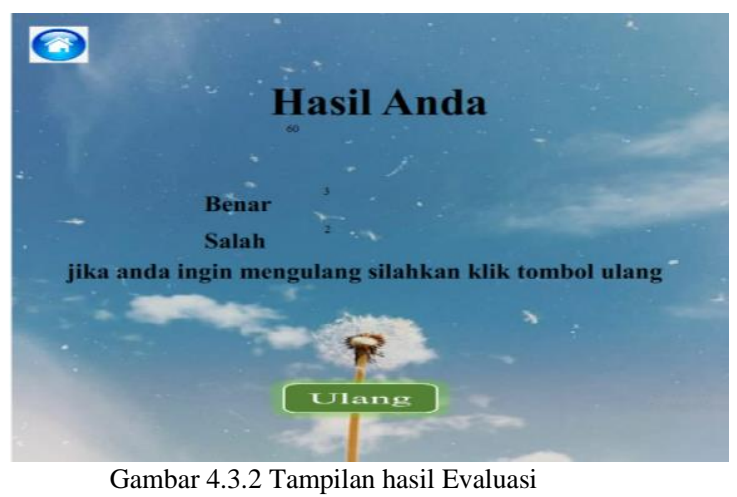

Sebelum digunakan media pembelajran interaktif ini dilakukan ujicoba oleh guru untuk melihat kesesuainya dengan kebutuhan pembelajaran matematika. Hasil ujicoba kepada guru ini diperoleh melalui wawancara yang mencakup 4 aspek yaitu: manfaat dan kegunaan media, kemudahan media, kemenarikan media, dan kesesuaian materi dengan SKKD. Hasil analisis dari tanggapan guru pada saat percobaan media memberikan hasil bahwa media pembelajaran ini bermanfaat dan berguna untuk membantu proses belajar siswa secara mandiri, media pembelajaran ini juga mudah untuk digunakan, serta mampu menarik perhatian siswa pada proses pembelajaran, materi yang ada di dalam mediajuga sudah sesuai dengan tujuan indikator pencapaian pada SKKD yang ada di sekolah.

Hal-hal yang mendukung tanggapan guru tersebut yaitu guru merasa termotivasi dengan melihat media pembelajaran interaktif ini, karena melihat media-media yang digunakan guru sebelumnya hanya sebatas lidi/korek api dan batu kecil yang dirasa kurang menarik dan masih konvensional. Sehingga dapat disimpulkan bahwa media pembelajaran interaktif berbasis multimedia ini dapat dijadikan alat bantu guru dalam proses pembelajaran matematika dan dapat dijadikan bahan latihan siswa untuk belajar secara mandiri. Dari pelaksanaan proses pembelajaran diperoleh beberapa hasil analisa data. Analisa data yang pertama adalah data dari observasi pada penilaian aspek minat belajar siswa. Data dari observasi diperoleh dengan menggunakan cheklist dari penilaian aspek minat yang terdiri dari 3 indikator yaitu perhatian, ketertarikan, dan keterlibatan siswa. Data yang diperoleh pada saat observasi minat siswa diolah untuk mengetahui persentase minat belajar siswa pada kelas kontrol dan eksperimen.

\section{KESIMPULAN}

Berdasarkan analisa dan pembahasan pada bab sebelumnya maka penulis dapat menarik kesimpulan bahwa penerapan Media pembelajaran yang dibuat interaktif berbasis multimedia dapat meningkatkan minat belajar siswa dalam mempelajari bilangan bulat pada mata pelajaran matematika di SMP karena memberikan pengalaman bermakna melalui tampilan menarik dan kegiatan evaluasi. Minat siswa dalam pembelajaran yang menggunakan media tersebut termasuk dalam kategori sangat baik pada aspek perhatian siswa terhadap pembelajaran terhadap ketertarikan siswa, sementara itu aspek keterlibatan siswa dalam pembelajaran pada kategori baik karena mengikuti evaluasi pada setiap soal-soal yang diberikan. Kondisi ini sangat jauh berbeda jika dibandingkan dengan kelas konvensional yang mana dalam semua aspek minat belajar siswa sangat kurang karena belajar dengan cara konvensional membosankan dan sulit di mengerti. Minat belajar siswa yang sangat baik ini kemuadian sejalan dengan capaian hasil berlajar siswa yang lebih tinggi pada kelas menggunakan media interaktif di banding kelas konvensional. Selain itu tanggapan siswa juga menunjukkan bahwa media pembelajran interaktif berbasis multimedia tersebut memiliki tampilan yang menarik, mudah digunakan dan memudahkan mereka dalam memahami pelajaran sehingga dapat dikatakan bahwa media ini dapat membantu pembelajaran matematika pada pokok bahasan bilangan bulat. 
48 Indonesian Journal of Technology, Informatics and Science (IJTIS), Vol. 1, No. 2, Juni 2020, hlm. 43-48

\section{DAFTAR PUSTAKA}

Borovcnik, M., \& Kapadia, R. 2009. Research Developments In Probability Education. International Electronik Journal Of Mathematics Education, 4, 11-130.

Dewi, R. K. (2011). Pengembangan Multimedia Pembelajaran Matematika "Math-Tainment" Materi Pokok Garis Dan Sudut Untuk Smp Kelas Vii. Universitas Negeri Yogyakarta.

Muhammad Istiqlal (2017).Pengembangan Multimedia Interaktif Dalam Pembelajaran Matematika.

Rahmat Riyanto,Fitri Dwi Kusuma,Sri Purwanti Nasution,Bambang Sri Anggoro (2018). Multimedia Pembelajaran Matematika Interaktif Berbasis Computer.

Ratri Candra Hastar(2013). Pembuatan Media Pembelajaran Matematika Interaktif Berbasis Powerpoint Bagi Guru-Guru Smp/ Mts SeKecamatan Kalidawir Tulungagung. 